\title{
MAPPING THE DISTRIBUTION OF BURIED GLACIER ICE - AN EXAMPLE FROM LAGO DELLE LOCCE, MONTE ROSA, ITALIAN ALPS
}

by

W. Haeberli

(VAW/ETHZ, Zürich, Switzerland)

and

F. Epifani

(Arona, Italy)

\begin{abstract}
Techniques for mapping the distribution of buried glacier ice are discussed and the results, from a study carried out within the framework of flood protection work in the Italian Alps, are presented. Bottom temperatures of the winter snow cover (BTS) primarily indicate the heat flow conditions in the underlying ground and mainly depend on the presence or absence of an ice layer beneath the surface. Determination of BTS values is therefore an inexpensive method for quickly mapping the near-surface underground ice in areas where there is $1 \mathrm{~m}$ or more of winter snow cover. At greater depths, and/or when more detail is required, geoelectrical resistivity soundings and seismic refraction soundings are most commonly used to investigate underground ice. A combination of the two sounding techniques allows the vertical extent and the main characteristics (frozen ground, dead glacier ice) to be determined in at least a semi-quantitative way. Complications mainly arise from irregularity in the horizontal extension of the studied underground ice bodies, and they may have to be overcome by expensive core drillings and borehole measurements. Widespread occurrence of buried glacier ice was observed in morainic deposits, surrounding an ice-dammed lake near Macugnaga, Italy.
\end{abstract}

\section{INTRODUCTION}

The existence and extent of dead glacier ice in recently exposed morainic deposits is, even today, rarely studied systematically. Only limited experience is available if detailed information is required for practical purposes. It is the aim of the present contribution to discuss briefly the techniques which can be applied in such situations and to propose a time- and cost-saving sequence of measurements, to approach the rather difficult task of mapping buried glacier ice. Recent observations, made in connection with flood protection work in the Italian Alps, are used to illustrate various aspects involved.

Lago delle Locce is an ice-dammed lake at the confluence of Ghiacciaio delle Locce and Ghiacciaio del Belvedere, Valle Anzasca, Monte Rosa region, Italian Alps (Fig.1). In 1979, the lake emptied through the ice of Ghiacciaio delle Locce, the probable cause being the progressive enlargement of ice channels (cf. Haeberli 1983). The outburst flood followed the eastern margin of Ghiacciaio del Belvedere, cut through its right lateral moraine near Alpe Pedriola, and triggered a mud flow, which caused heavy damage near Macugnaga, the nearby mountain village. In order to prevent further lake outbursts, a tube for lake level regulation was installed in front of Ghiacciaio delle Locce; this tube is presently being overridden by the advancing glacier. As a consequence, the construction of a new outlet structure, at a greater distance from the advancing ice front, had to be planned. The distribution of buried glacier ice was investigated within the framework of glaciological consulting work for this project (VAW 1984)

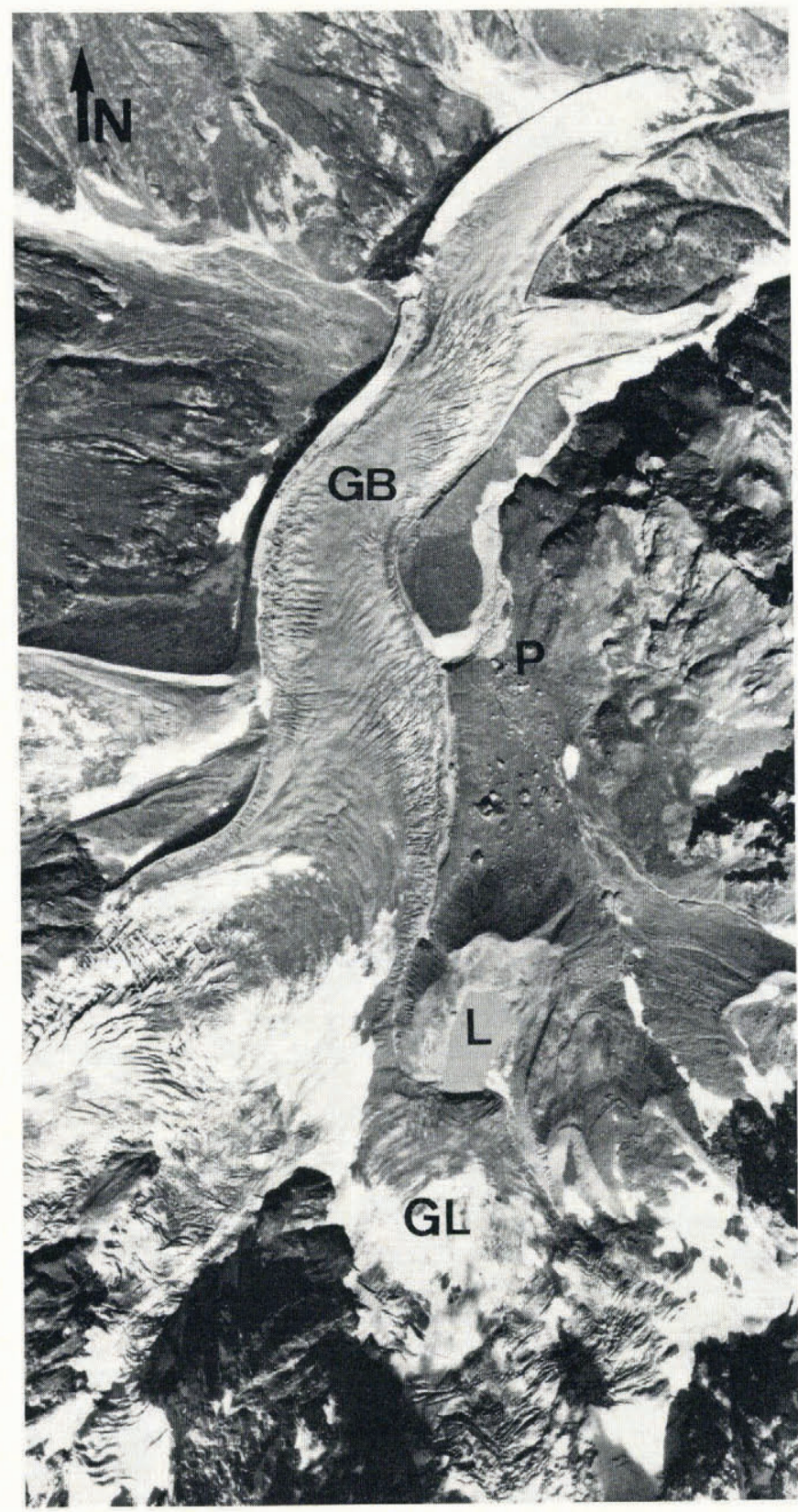

Fig.1. Lago delle Locce (L), Ghiacciaio delle Locce (GL) and Ghiacciaio del Belvedere (GB). The outburst flood of 1979 cut through the right lateral moraine of Ghiacciaio del Belvedere, near Alpe Pedriola (P). Vertical aerial photograph, taken in autumn 1983. 


\section{APPLIED TECHNIQUES}

In order to get reliable results with the minimum financial outlay, a combination of geophysical soundings and drillings was used. The geophysical soundings included indirect measurements of near-surface heat flow, geoelectrical resistivity, and seismic refraction. The positions of the measurements and soundings are indicated in Figure 2, which also gives the aerophotogrammetrically-determined topography (flight date 1983) of the lake basin, with its surrounding moraines.
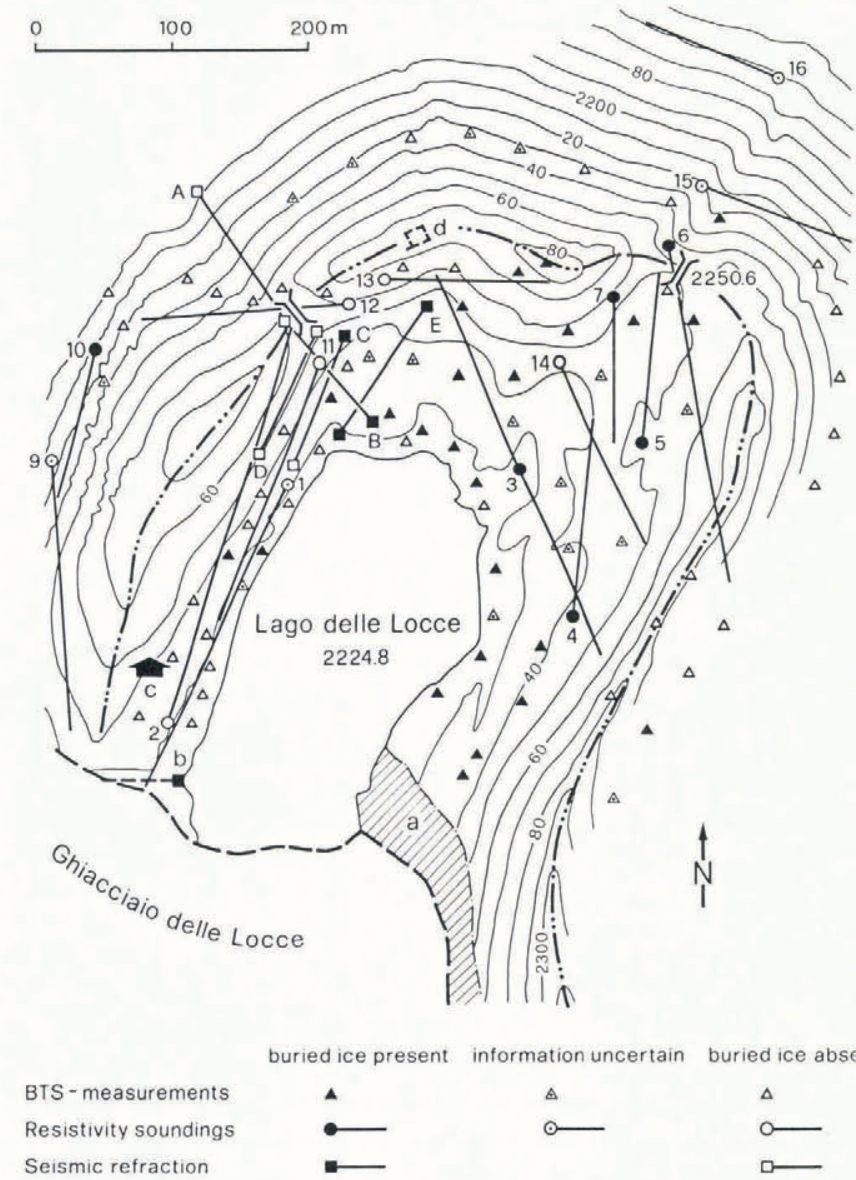

Fig.2. Lago delle Locce and surrounding moraines, with positions of soundings and measurements. $a=$ avalanche cone, $b=$ tube for lake-level regulation (partly overridden by the front of Ghiacciaio delle Locce), $c=$ temporary huts for construction work, $d=$ tilted foundation of destroyed Rifugio Paradiso. The dashed-dotted line indicates the crests of the moraines which surround the lake.

Bottom temperatures of the winter snow cover (BTS) were measured first, in order to map the distribution of the near-surface underground ice. So far, the method has been mainly applied to Alpine permafrost (Haeberli 1978, Haeberli and Patzelt 1983, King 1983, Müller 1983). It is based on the fact that the winter snow cover, with its low thermal conductivity, filters out high-frequency variations of air temperatures. BTS values are only slightly dependent on snow cover thickness, as long as the latter is not less than about $1 \mathrm{~m}$ (Fig.3). They primarily reflect heat flow conditions from the underlying ground and indicate the presence or absence of cold (ice) layers beneath the surface; BTS values lower than $-3^{\circ} \mathrm{C}$ indicate the presence of underground ice, whereas values higher than $-2{ }^{\circ} \mathrm{C}$ exclude the possibility that ice exists within the uppermost 4 to $6 \mathrm{~m}$. The uncertainty range of interpretation is -2 to $-3^{\circ} \mathrm{C}$. In permafrost, it is possible to obtain rough estimates of the depth to the perennial underground ice (permafrost table), on the basis of an empirical relationship between BTS values and (seismically determined) active-layer thickness (Haeberli and Patzelt 1983). However, it is not yet clear

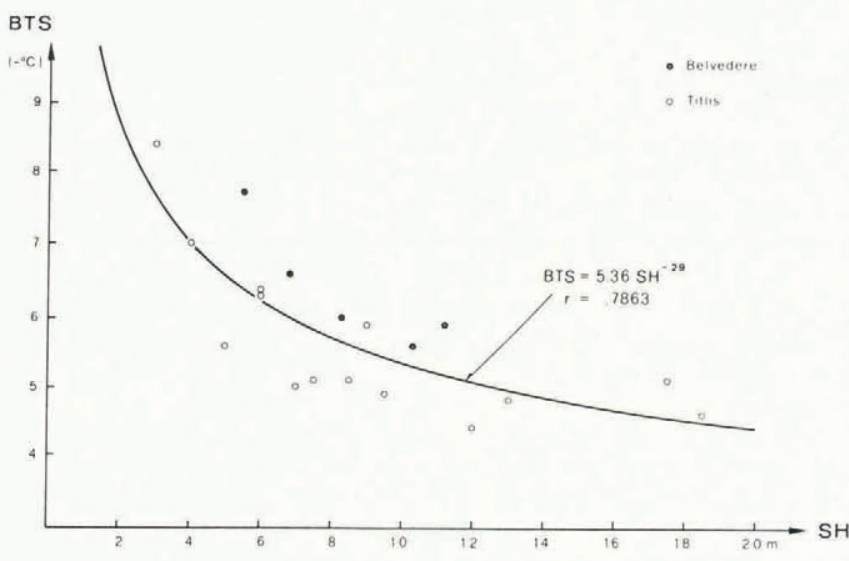

Fig.3. BTS values, measured over bare ice in February 1984. Influence of snow height (SH) is small if snow cover thickness is more than about 0.8 to $1 \mathrm{~m}$.

whether a similar relationship can be established and applied to dead glacier ice, which is embedded within non-frozen sediments. Measurements at Lago delle Locce were carried out in February 1983, using thermistor probes which were lowered to the soil-snow interface. Results of these measurements gave a good overview of the distribution of near-surface underground ice. They cannot, however, be used to discriminate between buried glacier ice and frozen ground, nor do they give any information about deeper layers.

Fif teen electrical D.C. resistivity soundings were carried out in the summer of 1983 (Fig.2), to investigate the following questions: 1) was the underground ice frozen ground, or buried glacier ice? 2) what was the vertical extent of the ice bodies? 3) had ice to be expected at greater depths? The technique is a classsical method in permafrost studies (Scott et al. 1979) and has been repeatedly used for investigations of ice-cored moraines (Østrem 1962, 1964) and rock glaciers (Fisch et al. 1978, Haeberli 1985). Specific resistivities of temperate and neartemperate glacier ice are in the $\mathrm{M} \Omega \mathrm{m}$ range, i.e., orders of magnitude larger than those of frozen ground, Discrimination between frozen and non-frozen ground, however, can be difficult, first because of the influence of lithology and, secondly, because of the fact that permafrost, near to $0^{\circ} \mathrm{C}$, can exhibit low resistivities. Examples of curves measured at Lago delle Locce are given in Figure 4. Buried glacier ice of about $1 \mathrm{~m}$ thickness was encountered at shallow depth within profile 14 , whereas profile 4 seems to indicate a more deeply-lying ice body of lower resistivity

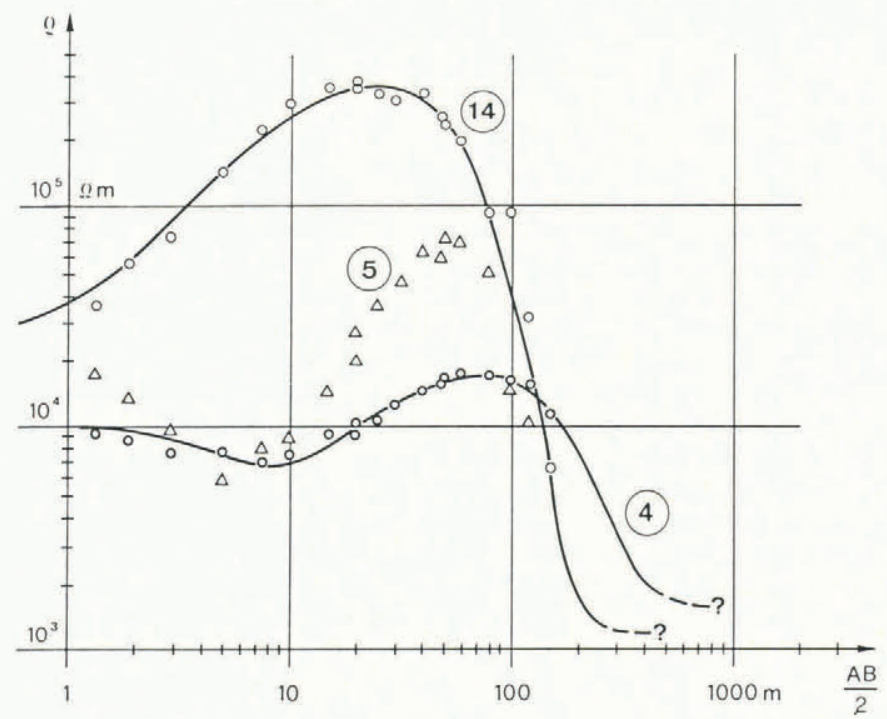

Fig.4. Examples of electrical (D.C.) resistivity soundings at Lago delle Locce (cf., text). A Schlumberger-Hummel prospecting configuration was used. 
$(60 \mathrm{k} \Omega \mathrm{m}$, inactive permafrost?). Profile 5 cannot be interpreted quantitatively, because of the over-steepened slopes of the resistivity curve, but it certainly revealed a $\mathrm{M} \Omega \mathrm{m}$ (dead) ice body, of limited horizontal extension, at a few metres depth. No high-resistivity ice bodies were detected within the profiles $2,11,12$, and 13 , and no clear indications were found that ice existed at depths well below the lake level. Bedrock seems to occur at considerable depth (around $80 \mathrm{~m}$ ), in the area of the profiles 2 and 11 .

Five seismic refraction profiles were measured in the summer of 1984 to investigate, in detail, the most appropriate place for the planned construction work at the NW corner of the lake (Fig.2). The main aims of the soundings were to clarify remaining questions about the occurrence of ground water and deep-seated permafrost and also to define the limits of the underground ice more precisely. Common values of $\mathrm{P}$-wave velocities are: $0.5-1.0$ $\mathrm{km} / \mathrm{s}$ in non-consolidated, non-frozen, morainic sediments without ground water, $1.5-2.5 \mathrm{~km} / \mathrm{s}$ in water-saturated sediments, $2.5-4.5 \mathrm{~km} / \mathrm{s}$ in perennially-frozen, ice-rich sediments, $3.3-3.8 \mathrm{~km} / \mathrm{s}$ in temperate or near-temperate glacier ice, and 5.0-6.0 km/s in solid bedrock (Haeberli 1985, Röthlisberger 1972). Figure 5 gives an example of seismic refraction profiles at Lago delle Locce. Neither

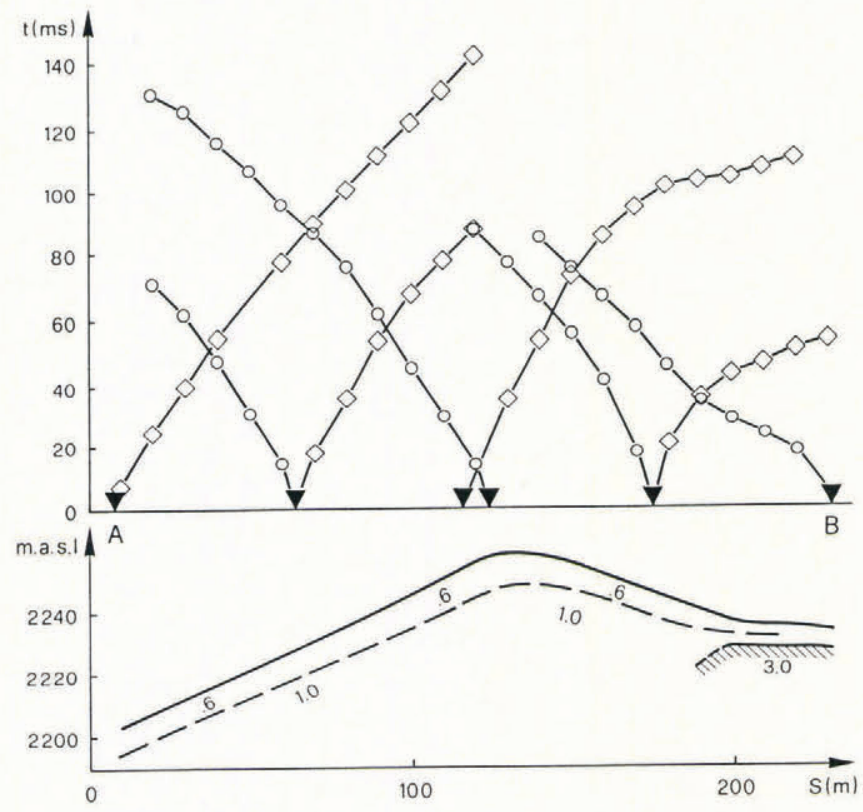

Fig.5. Examples of seismic refraction soundings at Lago delle Locce. Time $(t)$ is in milliseconds, $s=$ distance in metres, P-wave velocities are in $\mathrm{km} /$ second.

ground water nor bedrock was encountered and the buried ice at the lake border (point B) had a remarkably low P-wave velocity, probably due to its limited size and advanced stage of thermal disintegration.

\section{RESULTS AND CONCLUSIONS}

Results of the measurements and soundings are summarized in Figure 6. A considerable part of the moraine slopes, which surround the lake, are underlain by ice. Most of the near-surface underground ice appears to be high-resistivity (glacier or avalanche) ice of limited vertical extent (a few metres). Indications are such that marginallyactive permafrost could be present, possibly reaching a depth of around 30 to $40 \mathrm{~m}$ in slopes which are generally exposed to the W or NW. Especially at the north-eastern corner of the basin, near point $2250.6 \mathrm{~m}$, the deepest saddle within the terminal moraine, masses of dead glacier ice seem to be embedded within frozen sediments. In contrast, south-easterly-exposed slopes of the left lateral moraine contain much less ice. Between the north-western corner of the lake and point $2255.8 \mathrm{~m}$, the second deepest saddle of the terminal moraine, a passage ( $P$ in Fig.6), which is free of underground ice, can be found. Along this passage, the ground-water table and the bedrock surface both appear to be below lake level.
Masses of dead glacier ice, which are embedded within non-frozen sediments, are not in a state of thermal equilibrium. Thawing of such ice directly affects settlement processes within the overlying sediments; terrain deformation, due to such processes, is believed to be the reason for the recent destruction of Rifugio Paradiso, on the terminal moraine. The tilted foundations of this former mountain hut are visible still today, between point $2255.8 \mathrm{~m}$ and point $2250.6 \mathrm{~m}$ (Figs. 2 and 6). Buried ice bodies

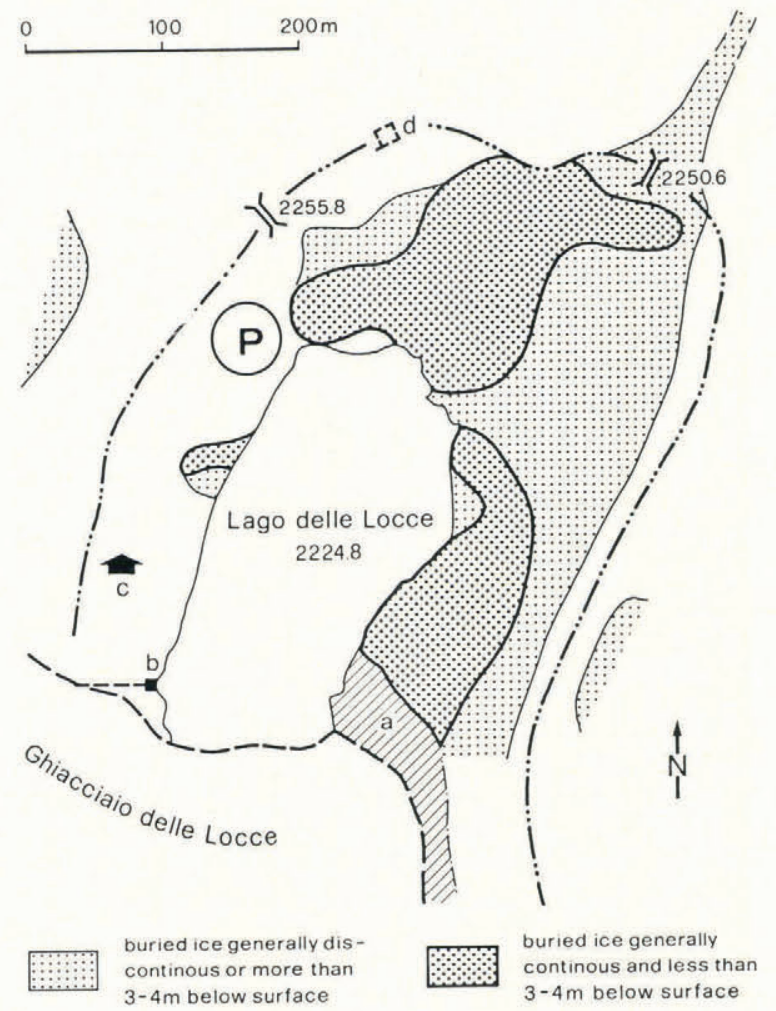

Fig.6. Distribution of buried glacier ice around Lago delle Locce. $\mathrm{a}=$ avalanche cone, $\mathrm{b}=$ tube for lake-level regulation (partly overridden by the front of Ghiacciaio delle Locce), $\mathrm{c}=$ temporary huts for the construction work, $d=$ tilted foundation of destroyed Rifugio Paradiso, $\mathrm{P}=$ ice-free passage, near point $2255.8 \mathrm{~m}$. The dashed-dotted line indicates the crests of the moraines which surround the lake.

would also be able to transmit stresses, induced by the advancing glacier, over large distances and, hence, could deform an artificial structure well before it experiences direct contact with an advancing ice front. For these reasons, the emplacement of the new outlet structure (a deep cut) was chosen to be the ice-free passage mentioned above, near point $2255.8 \mathrm{~m}$. Shallow core drillings and borehole measurements (water level, temperature, porosity) were performed in the summer of 1985 , as a final test of geotechnical conditions at the new construction site. Construction work also started in 1985 .

\section{ACKNOWLEDGEMENTS}

Thanks are due to the Communità Montana della Valle Anzasca for permission to publish results of this study. Dr W. Fisch, Wettswil, and Professor H. Röthlisberger, VAW/ETHZ, assisted in the planning and interpretation of the resistivity soundings and critically read the manuscript. A number of colleagues helped with the field work, Pamela Alean edited the English of the present report and Werner Nobs prepared the drawings.

\section{REFERENCES}

Fisch W Sr, Fisch W Jr, Haeberli W 1978 Electrical D.C. resistivity soundings with long profiles on rock glaciers and moraines in the Alps of Switzerland. Zeitschrift für Gletscherkunde und Glazialgeologie 13(1/2), 1977: 239-260 
Haeberli W 1978 Special aspects of high mountain permafrost methodology and zonation in the Alps. Proceedings of the Third International Conference on Permafrost, July 10-13, 1978, Edmonton, Alberta, Canada. Vol 1: 379-384

Haeberli W 1983 Frequency and characteristics of glacier floods in the Swiss Alps. Annals of Glaciology 4: 85-90

Haeberli W 1985 Creep of mountain permafrost: internal structure and flow of Alpine rock glaciers. Mitteilungen der Versuchsanstalt für Wasserbau, Hydrologie und Glaziologie an der Eidgenössischen Technischen Hochschule (Zürich) 77

Haeberli W, Patzelt G [1983] Permafrostkartierung im Gebiet der Hochebenkar-Blockgletscher, Obergurgl, Ötztaler Alpen. Zeitschrift für Gletscherkunde und Glazialgeologie 18(2), 1982: 127-150

King L 1983 High mountain permafrost in Scandinavia. Proceedings of the Fourth International Conference on Permafrost, July 17-22, 1983. Washington, DC, National Academy Press: 612-617

Müller H-N 1983 Messungen zum aktuellen Gletschervorstoss und Verbreitung von Untergrundeis im Vorfeld des Rossbodengletschers (Simplon, Schweizer Alpen). Innsbrucker Geographische Studien 8: 45-58

Østrem G 1962 Ice-cored moraines in the Kebnekajse area. Biuletyn Peryglacjalny 11: 271-278

Østrem G 1964 Ice-cored moraines in Scandinavia. Geografiska Annaler 46(3): 282-337

Röthlisberger H 1972 Seismic exploration in cold regions. US Army Cold Regions Research and Engineering Laboratory. Cold Regions Science and Engineering Monograph II-A2a

Scott W J, Sellmann P V, Hunter J A 1979 Geophysics in the study of permafrost. Proceedings of the Third International Conference on Permafrost, July 10-13, 1978 , Edmonton, Alberta, Canada. Vol 2: 93-115

VAW (Versuchsanstalt für Wasserbau) Unpublished Ricerche glaciologiche al Lago delle Locce, Macugnaga, Italia. VAW-Relazione 97.2 (Internal report) 